\title{
Academic Goals in Relation to Motivational Self-Regulation Value Strategies
}

\section{Las metas académicas con relación a las estrategias de autorregulación motivacional de valor}

\author{
José Manuel Suárez (*) jmsuarez@edu.uned.es \\ Ana Patricia Fernández (*) apfernandez@edu.uned.es \\ Ángela Zamora (*) angzamora@gijon.uned.es \\ (*) Universidad Nacional de Educación a Distancia \\ (Received: November 4, 2016; accepted for publishing: February 2, 2017)
}

How to cite: Suárez, J. M., Fernández, A. P. y Zamora, A. (2018). Academic goals in relation to motivational self-regulation value strategies. Revista Electrónica de Investigación Educativa, 20(2), 15-24. Retrieved from https://doi.ora/10.24320/redie.2018.20.2.1689

\begin{abstract}
The benefits of self-regulated learning have been confirmed. However, research is still pending on motivational self-regulation. We studied the use of attainment value and cost strategies in a study sample of 821 secondary education students. Our results showed that the students made considerable use of both strategies, that these strategies correlated positively with each other, that females made a significantly greater use of the cost strategy, and that greater use of each of the strategies was associated with a distinct multiple-goal student group. The results also enabled us to construct a general explanatory model of these strategies based on academic goals and self-efficacy, and independent of students' sex or multiple-goal group.
\end{abstract}

Keywords: Self-motivation, learning, student motivation, academic goals.

\section{Resumen}

Los beneficios del aprendizaje autorregulado han sido confirmados; sin embargo, sigue pendiente la investigación sobre la autorregulación motivacional. En este trabajo se analizó la utilización de las estrategias de exaltación del valor de consecución y de valoración del coste en 821 estudiantes de Secundaria. Los resultados muestran que las dos estrategias son utilizadas de forma considerable por los estudiantes y que correlacionan positivamente entre sí; se obtienen diferencias en la estrategia de valoración del coste a favor de las mujeres y una mayor utilización de las estrategias se asocia a un grupo distinto de múltiples metas. Los resultados también permitieron elaborar un modelo general explicativo de estas estrategias en función de las metas académicas y de la autoeficacia independientemente del sexo o grupo de múltiples metas de los estudiantes.

Palabras clave: Automotivación, aprendizaje, motivación de los estudiantes, metas académicas. 


\section{Introduction}

The rejection of memory-based educational approaches and the consideration of students as active participants have together given rise to an area of research focused on the concept of self-regulated learning (SRL). The term SRL has been defined as the degree to which students are actively involved in their own learning process on a metacognitive, motivational and behavioral level (Zimmerman, 2013). According to this concept, students would use different types of process, of greater or lesser complexity, to tackle a given task. Thus, there are three key elements to consider in SRL: person, behavior, and the task setting.

Although evidence has been reported in the last three decades on the extensive benefits of SRL for students (DiFrancesca, Nietfeld, \& Cao, 2016; Isaacson \& Fujita, 2006; Järvenoja, Järvelä, \& Malmberg, 2015; Pintrich \& De Groot, 1990; Schwinger \& Stiensmeier-Pelster, 2012; Zimmerman, 2013), including in learning environments involving computer use (Zheng, 2016), research is still pending on some of the most basic components of SRL. Whereas the cognitive and behavioral components have received considerable research attention, studies on the motivational component have primarily focused on motivation rather than self-regulation of motivation and affect. However, motivational self-regulation or self-motivation strategies can play a very important role in the learning process, because they are aimed at generating and regulating motives and affect, which are pre-requisites for the initiation, regulation and maintenance of behavior. The regulation of motivation and affect implies greater student involvement in the learning process and entails more effort and more appropriate learning strategies. In turn, this promotes a higher level of academic achievement and satisfaction.

Studies on strictly motivational self-regulation strategies have focused on a number of specific selfmotivation strategies, such as self-handicapping, defensive pessimism and self-enhancement strategies (e.g. Clarke \& MacCann, 2016; Eronen, Nurmi, \& Salmela-Aro, 1998; Gibson \& Sachau, 2000; Kathryn \& Maureen, 2010; Midgley, Arunkumar, \& Urdan, 1996; Norem \& Cantor, 1986). Although these studies provide a thorough and detailed insight into specific self-motivation strategies or very specific techniques, they do not provide a general overview of these strategies and techniques in combination.

Notable attempts to address the combined study of various motivational self-regulation strategies include the five strategies proposed by Wolters (1998), which led to a subsequent proposal of six strategies (Wolters \& Benzon, 2013). For their part, Suárez \& Fernández $(2005,2011)$ tried to identify a more comprehensive motivational self-regulation framework and thus provide an overall view. They based this on the motivational structure described by Pintrich \& De Groot (1990), but also incorporated particular types of affective and motivational self-regulation strategies (Suárez \& Fernández, 2005), proposing three components of motivational self-regulation strategies: expectancy, value and affect. The strategic component of expectancy comprises self-motivation strategies that students may employ to stimulate motivation by activating, defending or regulating their self-image or self-esteem, making certain attributions or generating positive expectations. The strategic component of value consists of self-motivation strategies that students may use to stimulate motivation by establishing interests and values or generating academic goals. Lastly, the strategic component of affect is composed of selfmotivation strategies that students may use to generate, avoid or control emotions that may be related to their learning and the tasks they must perform. In the present study, we focused on attainment value and cost strategies, which in the above approach are part of the strategic component of value.

Through the attainment value strategy, students can generate positive thoughts and beliefs about whether the task to perform will confirm their capabilities, either broadly or in relation to a given type of content or activity. This would allow them to enhance the value of the task, and would generate student thoughts of the type "If I do well in this task, I will show others that I am very good at science". Meanwhile, the cost strategy enables students to generate thoughts that establish the cost involved in performing the task relative to the results achieved, based on an assessment of time, work and effort. This type of behavior is often adopted prior to performing a specific task. However, it can also occur when monitoring the performance of a task, as students realize that their initial assessment of the cost involved was inadequate. In this case, they would need to readjust the cost-benefit balance and rethink 
the situation, generating student thoughts such as "This type of task does not usually take long so it is worth trying to concentrate in order to do it well".

It has been observed that both of these motivational self-regulation strategies relate to and influence the use of metacognitive and cognitive strategies in learning and study activities (Suárez, Fernández, Rubio, \& Zamora, 2016). However, no studies have been conducted on the relationship between these selfmotivation strategies and affective and motivational variables in students. Such studies would need to take into account the role played by academic goals, as these are considered the most direct regulators of behavior (Elliot \& Church, 1997). Thus, SRL could even be described as student regulation of learning to achieve personal goals (Nietfeld, Shores, \& Hoffmann, 2014). The study of academic goals has provided a wealth of information on the influence of different types of academic goals on student motivation, learning strategies and academic performance. More recently however, the possibility has been raised that various goals may be operating simultaneously in students (Berger, 2012; Darnon, Dompnier, Gilliéron, \& Butera, 2010; Hyunjoo, 2012). Thus, the different types of goals are thought to simultaneously interact and influence the learning process. This would imply that their combined impact will differ from their individual effects; consequently, this notion of multiple goals was also taken into account in the present study. Another of the most important motivational variables to consider is selfefficacy, which can be described as one's belief in one's ability to organize and execute the actions necessary to achieve specific goals (Bandura, 1997). Self-efficacy refers to how one thinks one can do a given task and what one expects of one's own capacity in relation to that task. Hence, students who believe in their ability to achieve their desired goals are more likely to be motivated and achieve success in the corresponding tasks.

The two main aims of the present study were therefore to explore the use of the attainment value and cost strategies, and to obtain a model of the influence of academic goals and self-efficacy for performance on these motivational self-regulation strategies. A further aim was to determine whether the model was valid regardless of students' sex or multiple-goal profiles.

\section{Method}

\subsection{Participants}

A total of 821 students participated in this study, of whom $51.6 \%$ were male and $47.4 \%$ were female. Of these, $51.6 \%$ and $38.4 \%$ were in their third and fourth years, respectively, of compulsory secondary education, and $6.7 \%$ and $3.2 \%$ were in their first and second years, respectively, of post-compulsory secondary education. Their ages ranged from 14 to 19 years old, with a mean age of 15.29 . Some $96.3 \%$ of participants were Spanish and the remaining 3.7\% were of foreign origin.

\subsection{Variables and questionnaires}

Two questionnaires were used to collect data. The first questionnaire analyzed academic goals and the second, self-efficacy for performance and the self-motivation strategies studied, namely attainment value and cost strategies.

Academic goals were evaluated by means of the Academic Goals Questionnaire developed by Skaalvik (1997), which includes four different goal orientations: task orientation (e.g. "I try to improve my skills and abilities in class"), self-enhancing ego orientation (e.g. "I try to achieve a better grade than other students"), self-defeating ego orientation (e.g. "When I answer questions in class, I worry about what my classmates will think") and avoidance orientation (e.g. "I prefer to do as little as possible in class"). All items were answered on a five-point scale, from 1 (rarely) to 5 (very often). The factors obtained explained $59.51 \%$ of total variance and their Cronbach's alpha coefficients are shown in table 1 . The full questionnaire obtained an alpha of .684.

The second questionnaire assessed self-efficacy for performance (e.g. "I think I'll get very good marks this year") and the self-motivation strategies of attainment value (e.g. "When faced with a difficult task, I 
wonder whether it will allow me to confirm that I'm a good student") and cost (e.g. "When faced with a difficult task, I wonder whether it's worth the effort involved"). To evaluate self-motivation strategies, we used the corresponding items from the secondary education version of the value scale in the EEMA-vs (Suárez \& Fernández, 2011). Instrument items were answered on a five-point scale from 1 (strongly disagree) to 5 (total agreement). The factors obtained explained $61.95 \%$ of total variance and their Cronbach's alpha coefficients are shown in table I. The full questionnaire obtained an alpha of .787.

\subsection{Procedure}

The questionnaires were administered by interviewers throughout Spain, following the previously established, standardized procedure. Our high school student sample completed both questionnaires during regular class hours. Participation was voluntary and subjects were assured that their answers would remain confidential and that only the researchers would have access to the data. They were also told that this was not an examination and that the questionnaires should be completed anonymously. They were further informed that there were no right or wrong answers, only statements that to a greater or lesser extent might reflect their thoughts and behavior during learning and study.

\subsection{Data analysis}

First, the data obtained were used to conduct a series of descriptive and correlational analyses. These were performed using different types of academic goals (task, self-enhancing ego, self-defeating ego and avoidance orientations), self-efficacy for performance and the attainment value and cost strategies. Subsequently, we examined whether sex and classification of students into groups according to their motivation should be considered in subsequent analyses, as occurred in previous research (e.g., Suárez et al. 2016; Fernández, Anaya, \& Suárez, 2012a; Fernández, Anaya, \& Suárez, 2012b). To this end, various Student's t-tests were performed to determine the existence of sex differences with respect to the different types of academic goals, self-efficacy for performance and the attainment value and cost strategies. These differences were also assessed by means of Cohen's $d$ to estimate the effect size (Cohen, 1990), and thus the magnitude of the differences. Adhering to the general rule established by Cohen, an effect size of .20 was considered small, .50 was considered medium and .80 large. Subsequently, we conducted a brief cluster analysis based on the motivational variables studied to determine whether it would be possible to obtain different groups of students based on their motivation.

Lastly, we performed structural equation modeling using AMOS 22, in order to obtain an explanatory model of how the self-motivation strategies of attainment value and cost were affected by academic goals and self-efficacy for performance. It is used as an analogy to a previous model with cognitive, metacognitive and behavioral strategies (Suárez, Fernández \& Anaya, 2005). Three strategies can be adopted with structural equation modeling: confirmatory modeling, rival models and model development. To obtain the model described in this study and avoid a fully exploratory approach, we adopted the model development strategy, with which it was possible to consider different models according to sex and student motivation. The estimation technique used was maximum likelihood, and the estimation process used was direct estimation.

\section{Results}

\subsection{Descriptive and correlational study}

Table I shows the main results of the descriptive and correlational analyses, together with reliability indices for the instruments used for the different types of academic goals, self-efficacy for performance and the self-motivation strategies of attainment value and cost. The highest mean score was obtained for task orientation, followed by self-efficacy for performance. The results indicated that the two selfmotivation strategies significantly and positively correlated with each other and also with most of the motivational variables, with the exception of a significant and negative correlation with avoidance orientation. 
Table I. Means, standard deviations, and Cronbach's alphas and correlations between variables.

\begin{tabular}{|c|c|c|c|c|c|c|c|c|c|c|}
\hline & $a$ & $\mathrm{~m}$ & sd & 1 & 2 & 3 & 4 & 5 & 6 & 7 \\
\hline Task orientation (1) & .717 & 3.760 & .857 & 1 & $197 * *$ & $.072 *$ & $-.241 * *$ & $.332 * *$ & $.259 * *$ & .457 ** \\
\hline Self-enhancing ego orientation (2) & .786 & 2.687 & 1.006 & & 1 & $.280 * *$ & -.027 & $.236 * *$ & $.386 * *$ & $.215^{* *}$ \\
\hline Self-defeating ego orientation (3) & .826 & 2.757 & 1.087 & & & 1 & $.078 *$ & $-.144 * *$ & $.192 * *$ & .041 \\
\hline Avoidance orientation (4) & .662 & 3.012 & .953 & & & & 1 & $-.257 * *$ & $-.082 *$ & $-.192 * *$ \\
\hline Self-efficacy for performance (5) & .803 & 3.176 & 1.075 & & & & & 1 & $.235^{* *}$ & $.260 * *$ \\
\hline Attainment value strategy (6) & .703 & 2.889 & .896 & & & & & & 1 & $.503 * *$ \\
\hline Cost strategy (7) & .728 & 3.155 & .919 & & & & & & & 1 \\
\hline
\end{tabular}

\subsection{Considerations of students' multiple-goal profile groups and sex}

A difference-in-means analysis was conducted to determine whether it was necessary to consider students' multiple-goal profile groups and sex. The results of this analysis revealed that all academic goals with the exception of task orientation presented statistically significant differences according to sex (table II). Thus, females obtained a higher score for self-defeating ego orientation whereas males obtained higher scores for self-enhancing ego and avoidance orientations. Regarding self-efficacy for performance and the two self-motivation strategies, only the cost strategy presented a statistically significant difference by sex, in favor of females.

Table II. Means, standard deviations, Student's t-tests and Cohen's $d$ between males and females by academic goals, self-efficacy for performance and attainment value and cost strategies

\begin{tabular}{|c|c|c|c|c|c|c|c|c|}
\hline \multirow[t]{2}{*}{ Strategy } & \multirow[t]{2}{*}{ Sex } & \multirow[t]{2}{*}{$\mathrm{m}$} & \multirow[t]{2}{*}{ sd } & \multicolumn{2}{|c|}{$\begin{array}{l}\text { Levene's test for } \\
\text { equality of variances }\end{array}$} & \multicolumn{2}{|c|}{$\begin{array}{c}t \text {-test for equality } \\
\text { of means }\end{array}$} & \multirow[t]{2}{*}{ Cohen's $d$} \\
\hline & & & & $f$ & $p$ & $t$ & $P$ & \\
\hline Task orientation & $\begin{array}{l}\text { Male } \\
\text { Female }\end{array}$ & $\begin{array}{l}3.714 \\
3.823\end{array}$ & $\begin{array}{l}.830 \\
.880\end{array}$ & 3.483 & .062 & -1.821 & .069 & 0.127 \\
\hline Self-enhancing ego orientation & $\begin{array}{l}\text { Male } \\
\text { Female }\end{array}$ & $\begin{array}{l}2.757 \\
2.609\end{array}$ & $\begin{array}{r}.976 \\
1.041\end{array}$ & 1.757 & .185 & 2.089 & .037 & 0.146 \\
\hline Self-defeating ego orientation & $\begin{array}{l}\text { Male } \\
\text { Female }\end{array}$ & $\begin{array}{l}2.668 \\
2.854\end{array}$ & $\begin{array}{l}1.064 \\
1.114\end{array}$ & 1.073 & .301 & -2.427 & .015 & 0.171 \\
\hline Avoidance orientation & $\begin{array}{l}\text { Male } \\
\text { Female }\end{array}$ & $\begin{array}{l}3.173 \\
2.831\end{array}$ & $\begin{array}{l}.949 \\
.931\end{array}$ & .357 & .550 & 5.183 & .000 & 0.364 \\
\hline Self-efficacy for performance & $\begin{array}{l}\text { Male } \\
\text { Female }\end{array}$ & $\begin{array}{l}3.165 \\
3.192\end{array}$ & $\begin{array}{l}1.048 \\
1.102\end{array}$ & 1.353 & .245 & -.367 & .713 & 0.025 \\
\hline Attainment value strategy & $\begin{array}{l}\text { Male } \\
\text { Female }\end{array}$ & $\begin{array}{l}2.909 \\
2.863\end{array}$ & $\begin{array}{l}.888 \\
.912\end{array}$ & 1.466 & .226 & .725 & .468 & 0.051 \\
\hline Cost strategy & $\begin{array}{l}\text { Male } \\
\text { Female }\end{array}$ & $\begin{array}{l}3.071 \\
3.241\end{array}$ & $\begin{array}{l}.933 \\
.902 \\
\end{array}$ & .593 & .442 & -2.636 & .009 & 0.185 \\
\hline
\end{tabular}

In relation to students' adoption of multiple academic goals, we performed a cluster analysis on the data and found that students could be classified into three clear groups (table III) with different motivational characteristics, and that this classification was associated with a different use of the attainment value and cost strategies. The first group consisted of students who predominantly presented an avoidance orientation and who also obtained the highest score for this orientation. Students in the second group obtained the highest scores for the two ego-oriented goals (self-enhancing and self-defeating). The third group comprised students who obtained the highest scores for task orientation. In addition, students in this last group exhibited greater self-efficacy for performance and greater use of the cost strategy, whereas students in the second group showed greater use of the attainment value strategy, and students in the first group obtained lower scores for self-efficacy for performance and for the attainment value and cost strategies. 
Table III. Cluster centers for variables and students in each cluster

\begin{tabular}{l|c|c|c}
\hline & \multicolumn{3}{c}{ Cluster } \\
\cline { 2 - 4 } & 1 & 2 & 3 \\
\hline Task orientation & 3.20 & 4.04 & 4.14 \\
Self-enhancing ego orientation & 2.06 & 3.42 & 2.59 \\
Self-defeating ego orientation & 2.50 & 3.60 & 2.05 \\
Avoidance orientation & 3.33 & 3.24 & 2.33 \\
Self-efficacy for performance & 2.40 & 3.28 & 4.04 \\
Attainment value strategy & 2.30 & 3.41 & 3.00 \\
Cost strategy & 2.54 & 3.47 & 3.56 \\
Number of students in the cluster & 300 & 288 & 233 \\
\hline
\end{tabular}

\subsection{A model of the influence exerted by academic goals and self-efficacy for performance on attainment value and cost strategies, considering sex and adoption of multiple goals}

To determine the relationship between the different types of variable studied, a diagram of routes for a structural equation modeling analysis was specified in AMOS 22. The results suggest that once the fit indices were considered, the model in figure 1 (the general model) showed an acceptable fit to the data $\left(\chi^{2}(4)=5.711, p=.222\right)$ and the fit statistics provided corroborating evidence (table IV).

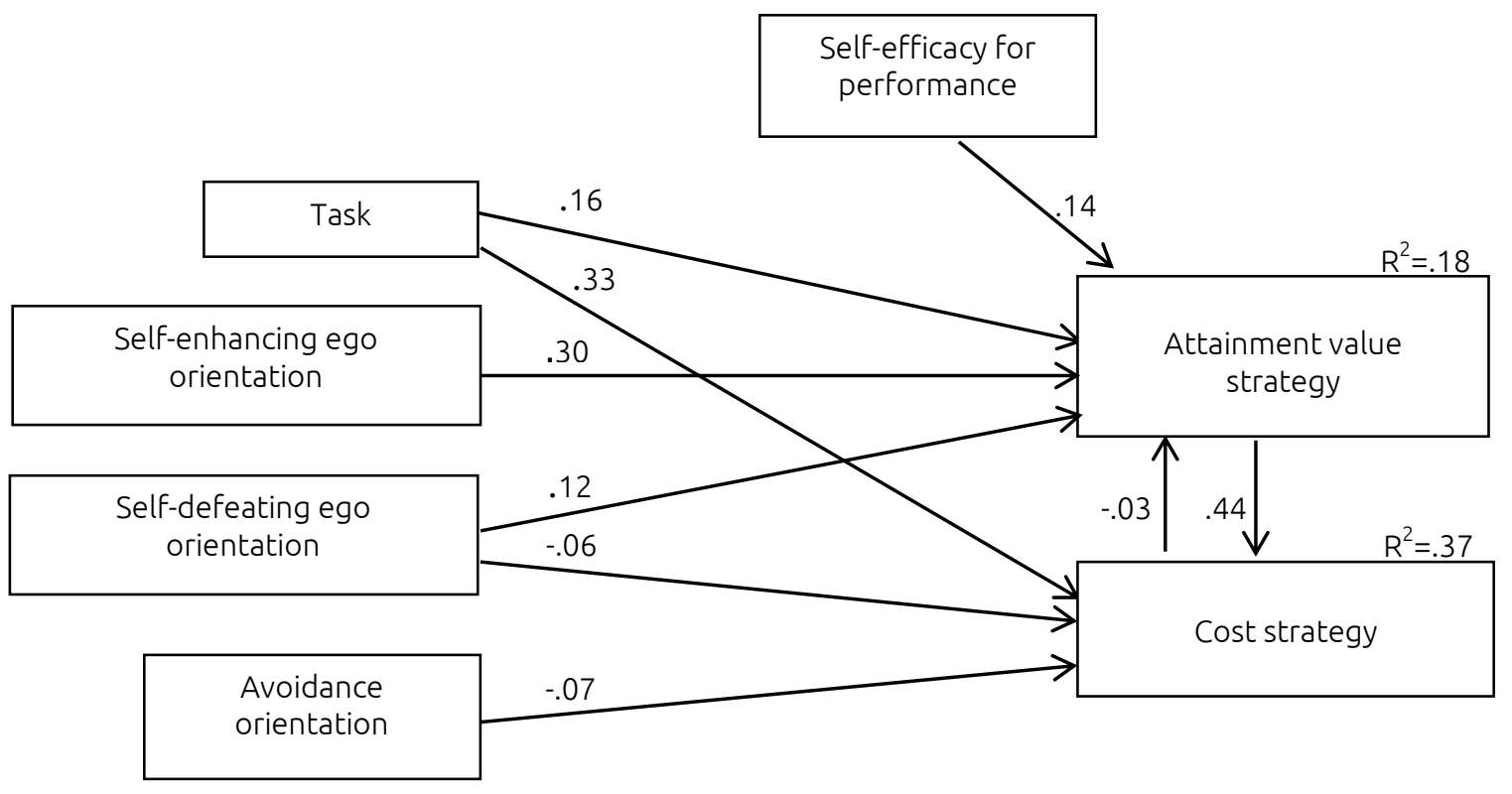

Figure 1. Explanatory model of the relationships between goals, self-efficacy for performance, and the attainment value and cost strategies

Note: Only the statistically significant $(p<.01)$ standardized regression coefficients are shown in the model.

Correlations have been omitted for ease of representation. 
Table IV. Results for model fit and its application to sex and multiple-goal clusters

\begin{tabular}{l|c|c|c|c|c|c|c|c|c|c}
\hline & $\chi^{2}$ & DF & $\begin{array}{c}\text { Probability } \\
\text { level }\end{array}$ & $\chi^{2} / \mathrm{DF}$ & GFI & AGFI & IFI & TLI & CFI & RMSEA \\
\hline General model & 5.711 & 4 & .222 & 1.428 & .998 & .986 & .998 & .990 & .998 & .023 \\
Males & 1.745 & 4 & .783 & 1.436 & .999 & .992 & 1.005 & 1.027 & 1.000 & .000 \\
Females & 5.640 & 4 & .228 & 1.410 & .996 & .971 & .997 & .982 & .997 & .033 \\
Cluster 1 & 4.186 & 4 & .381 & 1.047 & .996 & .972 & .998 & .990 & .998 & .012 \\
Cluster 2 & 3.217 & 4 & .522 & 0.804 & .997 & .978 & 1.005 & 1.032 & 1.000 & .000 \\
Cluster 3 & 1.896 & 4 & .755 & 0.474 & .998 & .984 & 1.032 & 1.223 & 1.000 & .000 \\
\hline
\end{tabular}

The results obtained indicate significant relationships from the four academic goals and self-efficacy for performance towards the two self-motivation strategies. All of these relationships were positive, except those from the avoidance and self-defeating ego orientations towards the cost strategy, which also exerted the least influence. The goals that exerted the most influence included task orientation on the cost strategy, and self-enhancing ego orientation on the attainment value strategy. The influence of the attainment value strategy on the cost strategy, which was the strongest influence in the model, should also be included in these results. Regarding the multiple squared correlation of both strategies, we obtained a considerably greater explanation of variance for the cost strategy than for the attainment value strategy.

Subsequently, we confirmed that the general model showed an acceptable fit to the data when applied solely to males $\left(\chi^{2}(4)=1.745, p=.783\right)$ or solely to females $\left(\chi^{2}(4)=5.640, p=.228\right)$. Once again, the fit statistics provided corroborative evidence in both cases (Table 4$)$. In addition, this also occurred when the model was applied to the three clusters based on students' multiple-goal profiles. Thus, the model was confirmed for cluster $1\left(\chi^{2}(4)=4.186, p=.381\right)$, cluster $2\left(\chi^{2}(4)=3.217, p=.522\right)$, and cluster $3\left(\chi^{2}(4)=1.896\right.$, $\mathrm{p}=.755)$.

\section{Conclusions and discussion}

The first noteworthy aspect revealed by the results is the evidence obtained for students' informed use of the attainment value and cost strategies. The values obtained were of a medium or even medium-high level when compared with the values for other variables. In addition, both strategies correlated highly, significantly and positively. This suggests that the students made frequent use of this type of strategy, to a greater extent than initially imagined. It also indicates that the use of both strategies was associated with high levels of student motivational self-regulation, directed towards both the pursuit of learning and academic achievement. In fact, in the model obtained, task and self-enhancing ego orientations exerted the strongest influence on these strategies. In particular, task orientation influenced both motivational self-regulation strategies, despite the fact that at first glance one might think that task orientation would not require the use of such strategies because this goal is defined by the pursuit and satisfaction of learning as an end in itself (Nietfeld et al., 2014; Skaalvik, 1997). However, it seems that implementing this type of strategy may benefit and help to sustain students' task orientation.

It is also worth mentioning that female subjects made greater use of the cost strategy, and also reported lower levels of avoidance orientation. Thus, males not only sought to avoid effort more than females, but also questioned the cost to a lesser extent, in terms of the effort, time and work involved in performing the task. In other words, male subjects were more predisposed to exert less effort without even considering whether the effort required to perform the task was worth it. In addition, this strategy was used to a greater extent by students in the multiple-goal group that obtained the highest scores for task orientation. This suggests that this greater predisposition towards task orientation, i.e. towards learning, could explain why students monitored their motivation and in consequence decided that the cost associated with the task was worth it. In fact, the strongest influence exerted by a goal in the proposed model was indeed that of task orientation on the cost strategy. 
Meanwhile, the attainment value strategy did not show differences by sex, but was reported to a greater extent by students with a greater orientation towards multiple goals in which the two ego orientations (self-enhancing and self-defeating) predominated. This is clearly explained if we consider that it was this group of students that obtained higher values with respect to the pursuit of achievement, whether in order to compare themselves with others or to avoid losing face. Thus, students would use the attainment value strategy to seek confirmation of their skills through achievement.

In light of the above, there appear to be clear indications of the need to consider sex (Petersen \& Hyde, 2014) and student groups classified according to their multiple-goal profiles (Berger, 2012; Darnon, Dompnier, Gilliéron, \& Butera, 2010; Hyunjoo, 2012). However, this is only the case if we consider some of the variables studied, and is not necessary when constructing a model of the relationship between variables. Thus, the model is confirmed regardless of whether we apply it to a single sex or a single group of students classified according to their multiple-goal profile. This confirms the importance of combining an in-depth, analytical study on the relationship between certain variables with another that incorporates a model providing a general overview.

Future research on self-regulated learning should consider not only the cognitive and behavioral components of self-regulated learning but also self-regulation of motivation (Zimmerman, 2013), exploring motivational self-regulation strategies as a whole, and attainment value and cost strategies in particular. These strategies can be explained to some extent by student goals and self-efficacy, and in turn stimulate the use of strategies that are most directly related to student learning, such as behavioral, metacognitive and cognitive strategies that determine the outcome of learning. All this knowledge will be of considerable value when planning educational interventions aimed at encouraging the efficient use of these strategies by students.

\section{References}

Bandura, A. (1997). Self-efficacy: The exercise of control. New York: Cambridge University Press.

Berger, J. (2012). Uncovering vocational students' multiple goal profiles in the learning of professional mathematics: Differences in learning strategies, motivational beliefs and cognitive abilities. Educational Psychology, 32(4), 405-425. doi:10.1080/01443410.2012.674663

Clarke, I. E., \& Maccann, C. (2016). Internal and external aspects of self-handicapping reflect the distinction between motivations and behaviours: Evidence from the Self-handicapping Scale. Personality and Individual Differences, 100, 6-11. doi:10.1016/j.paid.2016.03.080

Cohen, J. (1990). Things I have learned (so far). American Psychologist, 45(12), 1304-1312.

doi:10.1037/0003-066x.45.12.1304

Darnon, C., Dompnier, B., Gilliéron, O., \& Butera, F. (2010). The interplay of mastery and performance goals in social comparison: A multiple-goal perspective. Journal of Educational Psychology, 102(1), 212222. doi:10.1037/a0018161

Difrancesca, D., Nietfeld L. J, \& Cao, L. (2016). A comparison of high and low achieving students on selfregulated learning variables. Learning and Individual Differences, 45, 228-236.

doi.org/10.1016/j.lindif.2015.11.010

Elliot, A. J., \& Church, M. A. (1997). A hierarchical model of approach and avoidance achievement motivation. Journal of Personality and Social Psychology, 72(1), 218-232.

Eronen, S., Nurmi, J. E., \& Salmela-Aro, K. (1998). Optimistic, defensive-pessimistic, impulsive and selfhandicapping strategies in university environments. Learning and Instruction, 8(2), 159-177.

doi: 10.1016/s0959-4752(97)00015-7 
Fernández, A. P., Anaya, D. \& Suárez, J. M. (2012a). Motivation features and motivational self-regulatory strategies in the middle school students. Revista Psicodidáctica, 17(1), 95-111.

Fernández, A. P., Anaya, D. \& Suárez, J. M. (2012b). Niveles motivacionales en los estudiantes de Secundaria y su discriminación en función de las estrategias motivacionales [Motivational levels in high school students and their discrimination in terms of motivational strategies]. Revista Española de Orientación y Psicopedagogía, 23(1), 50-65.

Gibson, B., \& Sachau, D. (2000). Sandbagging as a self-presentational strategy: Claiming to be less than you are. Personality and Social Psychology Bulletin, 26(1), 56-70. doi:10.1177/0146167200261006

Hyunjoo, L. (2012). Effects of goal relations on self-regulated learning in multiple goal pursuits: Performance, the self-regulatory process, and task enjoyment. Asia Pacific Education Review, 13(2), 369386. doi:10.1007/s12564-012-9216-y

Isaacson, R., \& Fujita, F. (2006). Metacognitive knowledge monitoring and self-regulated learning: academic success and reflections on learning. Journal of the Scholarship of Teaching and Learning, 6(1), 3955.

Järvenoja, H., Järvelä, S., \& Malmberg, J. (2015). Understanding regulated learning in situative and contextual fremworks. Educational Psychologist, 50(3), 204-219. doi:10.1080/00461520.2015.1075400

Kathryn, O., \& Maureen, S. (2010). The phenotypic expressions of self-doubt about ability in academic contexts: Strategies of self-handicapping and subjective overachievement. In A. Robert, O. Kathryn, \& C. Patrick (Eds.), Handbook of the uncertain self (pp. 379-398). New York: Psychology Press.

Midgley, C., Arunkumar, R., \& Urdan, T. C. (1996). "If I don't do well tomorrow, there's a reason": Predictors of adolescents' use of academic self-handicapping strategies. Journal of Educational Psychology, 88(3), 423-434. doi:10.1037/0022-0663.88.3.423

Nietfeld, J. L., Shores, L. R., \& Hoffmann, K.F. (2014).Self-regulation and gender within a game-based learning environment. Journal of Educational Psychology, 106(4), 961-973. doi:10.1037/a0037116

Norem, J., \& Cantor, N. (1986). Defensive pessimism; Harnessing anxiety as motivation. Journal of Personality and Social Psychology, 5(4), 1208-1217. doi:10.1037/0022-3514.51.6.1208

Petersen, J., \& Hyde, J. S. (2014). The role of gender in educational contexts and outcomes. In L. S. Liben, \& R. S. Bigler, (Eds.), Advances in child development and behavior, vol. 47 (pp. 43-76). San Diego, CA: Elsevier Academic Press.

Pintrich, P. R., \& De Groot, E. V. (1990). Motivational and self-regulated learning components of classroom academic performance. Journal of Educational Psychology, 82(1), 33-40. doi:10.1037/0022-0663.82.1.33

Schwinger, M., \& Stiensmeier-Pelster, J. (2012). Effects of motivational regulation on effort and achievement: A mediation model. International Journal of Educational Research, 56, 35-47.

doi:10.1016/j.ijer.2012.07.005s

Skaalvik, E.M. (1997). Self-enhancing and self-defeating ego orientation: Relations with task and avoidance orientation, achievement, self-perceptions, and anxiety. Journal of Educational Psychology, 89(1), 71-81. doi:10.1037/0022-0663.89.1.71

Suárez, J. M., \& Fernández, A. P. (2005). Escalas de evaluación de las estrategias motivacionales de los estudiantes [Assessment scales of students' motivational strategies]. Anales de Psicología, 21(1), 116-128. 
Suárez, J. M., Fernández, A. P. \& Anaya, D. (2005). Un modelo sobre la determinación motivacional del aprendizaje autorregulado [A model on motivational determination of self-regulated learning]. Revista de Educación, 338, 295-306.

Suárez, J. M., \& Fernández, A. P. (2011). Evaluación de las estrategias de autorregulación afectivomotivacional de los estudiantes: Las EEMA-Vs [Assessment of students' affective-motivational selfregulatory strategies: The MSLS-SV]. Anales de Psicología, 27(2), 369-380.

Suárez, J. M., Fernández, A. P., Rubio, V. \& Zamora, A. (2016). Incidencia de las estrategias motivacionales de valor sobre las estrategias cognitivas y metacognitivas en estudiantes de secundaria [Incidence of value motivational strategies on high school students' cognitive and metacognitive strategies]. Revista Complutense de Educación, 27(2), 421-435. doi: 10.5209/rev_RCED.2016.v27.n2.46329

Wolters, C. A. (1998). Self-regulated learning and college students' regulation of motivation. Journal of Educational Psychology, 90(2), 224-235. doi:10.1037/0022-0663.90.2.224

Wolters, C. A., \& Benzon, M. B. (2013). Assessing and predicting college students' use of strategies for the self-regulation of motivation. The Journal of Experimental Education, 81(2), 199-221.

doi.org/10.1080/00220973.2012.699901

Zheng, L. (2016). The effectiveness of self-regulated learning scaffolds on academic performance in computer-based learning environments: A meta-analysis. Asia Pacific Education Review, 17(2), 187-202. doi:10.1007/s12564-016-9426-9

Zimmerman, B. J. (2013). From cognitive modeling to self-regulation: A social cognitive career path. Educational Psychologist, 48(3), 135-147. doi:10.1080/00461520.2013.794676 